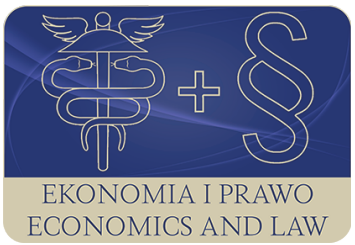

EKONOMIA I PRAWO. ECONOMICS AND LAW

Volume 17, Issue 4, December 2018

p-ISSN 1898-2255, e-ISSN 2392-1625

www.economicsandlaw.pl

ORIGINAL ARTICLE

received 02.01.2018; revised 10.05.2018; accepted 31.12.2018

Citation: Szelągowska-Rudzka, K. (2018). Direct participation of higher education institution employees in the organisational change process: study report. Ekonomia i Prawo. Ecomomics and Law, 17(4): 417-431. doi:10.12775/EiP.2018.030.

\title{
Direct participation of higher education institution employees in the organisational change process: study report
}

\author{
KATARZYNA SZELĄGOWSKA-RUDZKA \\ Gdynia Maritime University, Faculty of Entrepreneurship and Quality Science, Department \\ of Economics and Economic Policy, ul. Morska 81-87, 81-225 Gdynia, Poland \\ $\square$ k.szelagowska-rudzka@wpit.am.gdynia.pl
}

\begin{abstract}
Motivation: Changes in the organization's environment require its adjustment through the process of organisational change. For changes to bring expected, positive results, it is recommended that all employees be involved. Employee direct participation is one of the most effective methods of winning them for change and making them favour changes in the form of cooperation, engagement and reduction of resistance. In the literature, there are not too much studies focused on employee direct participation in the organisational change process at universities. Therefore, this area seems to be an interesting research field.

Aim: The objective of this study is to analyse the process of change of organisational structure (number of departments) at a faculty of a higher education institution in the Pomeranian Province, in terms of the direct participation of research and academic staff and teaching staff in this process. The study was conducted using quantitative methods (a questionnaire). The study sample (the faculty and its employees) was selected intentionally due to the usefulness of data sources.

Results: It was found that the selected employees participate in the change cycle in a limited way, with indifference and resistance being main attitudes to that change. Research

results suggest that the causes of that state include autocratic style of management on the part of change designers, little time devoted to involve employees in the process, and negative atmosphere caused by staff rotation (dominant internal factor).
\end{abstract}


Keywords: employee direct participation; organizational changes; higher education institutions; cycle of organisational change process; employee resistance to change

JEL: I23; M12; M54

\section{Introduction}

Organizational changes are a characteristic feature of today's organizations that have to adapt to the constantly transforming environment (i.e. technological progress, changes in customer needs and expectations, growing competition) (Spodarczyk, 2016, pp. 250-251). The effectiveness of the change process is inseparably connected to the social factor (Czerska, 1996, p. 145; Igielski, 2015, p. 216). It is the people who build up an organization, fulfil its mission and aims, as well as design and implement organizational changes. Hence it is significant that they display appropriate attitudes and behaviours towards changes. In order for employees to become allies of change, they must be attracted and involved in the process; the atmosphere and possibility of creative action must be introduced (Sobka, 2014, p. 32), and motivation for change, sense of security, access to information, time to get acquainted with and adapted to the change, and, above all, the possibility of direct participation in the whole process must be assured (Czerska, 1996, pp. 145-151; Hodgkinson, 1999, p. 2; Ignyś, 2014, pp. 26-28; Pawlak, 2015, pp. 60-61; Strykowska, 2010, pp. 11,14; Wittig, 2012, pp. 24-27; Zarębska, 2002, pp. 157, 197).

At present, universities in Poland are facing transformations (new law and principles for funding education and universities, globalization, demographic changes, labour market) which require introducing organizational changes (within universities). Therefore, it is crucial to ask a question whether and how research and academic staff and teaching staff participate in those changes being implemented at universities and, consequently, contribute to their more effective implementation.

The aim of the study is to analyse the process of changing the organizational structure (the number of departments) at a basic unit of one of the Pomeranian higher education institutions focusing on direct participation of research and academic staff and teaching staff in the process. The direct questionnaire method was applied as research method.

\section{Literature review}

Organizational changes are the process of modifying existing solutions to create another, more efficient, organizational model (Cabała, 2015, p. 134). They can be initiated by management and by employees (organic, participatory change) with the knowledge and motivation to implement them. According to P. Hersey and $\mathrm{K}$. Blanchard, the participatory cycle of changes leads to the involvement of employees (Koźmiński \& Piotrowski, 2013, p. 500), positively influences the efficiency and effectiveness of the process (Grobelna \& Marciszewska, 
2016b, p. 96; Ignyś, 2014, pp. 31-34; Sobka 2014, p. 15; Westhuizen et al., 2012). For the success of the whole enterprise it is crucial to involve the employees in the process (Spodarczyk, 2016, pp. 250-251). Therefore, attitudes and behaviours of the members of organization towards change (from cooperation through indifference to resistance) are so important to their course. The resistance to change (i.e. passive or active pursuit of the change not occurring, not persisted or not included) is the least desired and the most dangerous (Czermiński et al., 2001, pp. 515, 519; Strykowska, 2010, p. 14; Wittig, 2012, p. 25). As L. Clarke (1997, p. 109), points out resistance originates from the change being perceived as something done irrespective of employees, not with them. Therefore, employees should be given the opportunity to participate in the change. Employees involved in the process of organizational change from its first to the last stage - identify themselves with the change, understand the reasons for it, accept the solutions they are working on, and engage in their implementation because they participated in the decision-making process.

Direct employee participation is their collective and individual involvement in the decision-making process regarding the operation of organization at various levels of its hierarchy, and regarding the employees as participants and makers of processes, principles and conditions of their functioning in the organization's life. It can be a group or individual, it can use group work management techniques and methods (e.g. problem solving teams, autonomous teams, quality circles, goal management) and individual ones (e.g. work enrichment and design, flexible working time, remote work, cafeteria remuneration systems) (Moczulska, 2011, pp. 24-34). It has different qualities. It can address a variety of issues (content of participation) from the operational, tactical or strategic level of the organization (the scope), all (full participation) or selected (partial participation) stages of the decision-making process, be sanctioned or not with organizational regulations (formal, informal), and stand for the employees' real influence on the functioning of organization (actual) or be pseudo-participation (perceived). It may have a passive or active form (intensity). The first one - cooperation - is characterized by the employees' right to information, being heard, being able to speak out and advise. Co-decision in turn (active) includes the right of employees to express their opposition, consent, common dispute settlement and to decide independently (Szelągowska-Rudzka, 2015, p. 479). Thus, it constitutes their full participation in the decisions.

Among the determinants of employee direct participation, the management style (Summers \& Hymen, 2005, p. 34), attitudes and behaviours (also ethical) of superiors (Grobelna \& Marciszewska, 2016a, p. 139; Kizielewicz, 2015, p. 186; Mowbray et al., 2015, pp. 392-393) play an important role. Participatory (democratic) and consultative styles are believed to be conducive to participation; autocratic style is unfavourable (Moczulska, 2011, p. 45; Szelągowska-Rudzka, 2015, pp. 479-480). Application of the management style appropriate for employee direct participation leads to building proper reactions and dialogue with employees (Radomska, 2010, p. 102), treating them subjectively, with mutual 
respect, support (Grobelna et al., 2016, p. 286) and trust (Rees et al., 2013, pp. $2785,2792)$, recognition of the competence of employees resulting in the delegation of decision-making powers to them. Thoughtful executives engage subordinates in the change process, in the search for new solutions, their assessment and implementation. Such action ensures higher quality of decisions, synergy effect, larger acceptance of the decisions by those who made and will implement them (Robbins, 1998, p. 104).

Determinants of direct employee participation in the process of organizational change can be divided into external and internal part. The first are legal, economic, social, technical, and international factors (competition, globalization), as well as national culture. Internal determinants include: strategy of action (and personnel strategy), organizational factors (including organizational structure, communication), attitude towards people management, organizational culture, management style, employee factors, and financial conditions. The proper shaping of these factors supports employee participation in the cycle of organizational change process (Szelągowska-Rudzka, 2016a, pp. 52-53; Sobka, 2014, pp. 14-17). Their force of influence depends on a situation (Szelągowska-Rudzka, 2016a, p. 53).

Higher education institutions in Poland are currently experiencing transitions due to globalization, demographic problems, labour market changes and the changes in funding science and higher education in the face of a new law to be introduced. They need to adapt to them by implementing organizational changes. Here, as demonstrated earlier, employees play a significant part. Their direct participation in the process of change cycle may bring positive effects, also in the form of better adaptation to external conditions.

\section{Method}

The study was conducted by applying the direct questionnaire method (a form of direct measuring survey) (Kaczmarczyk, 1999, pp. 219, 227), based on a questionnaire developed by the author. It involved research and academic staff and teaching staff of one of the faculties of a public university in the Pomeranian Province.

The measuring instrument consisted of 11 questions and respondent's particulars. The questions concerned the willingness and ability to participate in the change, the intensity of participation (passive, active), key information sources, techniques and forms of participation (group, individual), management style, attitudes and behaviours of the change designers (the deanery) towards employees, employees' reactions to change, and internal and external determinants of these reactions. The study was conducted within 2 weeks in March 2017, following the Dean's written consent. The questionnaires were given to respondents personally or left in their departments' offices. Completed questionnaires were brought back to the offices or given directly to the author. 


\section{Results}

The study involved 61 people (out of 77 academic teachers employed), including $61 \%$ women and $39 \%$ men. The group consisted mainly of regular employees 85\% (15\% were managing staff), research and academic staff constituted 67\% (teaching staff $-33 \%$ ), employees with job seniority of 17-25 years constituted $49 \%$, those with job seniority of over 25 years - $28 \%$ (up to 8 years $10 \%, 9-16$ years $-13 \%$ ). Only $67 \%$ of respondents (41 people) provided their academic degree/title, and these were mainly $\mathrm{PhD}(71 \%)$ (professors - 12\%, associate professors $-10 \%$, holders of master's degree $-7 \%$ ). The results of the study are presented in tables 1-11.

Table 1 presents that $97 \%$ of staff care about smooth functioning of the faculty. Next 59\% (strongly agree and agree in total) are willing to participate in changing its organizational structure (number of departments) (table 2). The respondents would also like to submit ideas and suggestions for improvement concerning didactics - 84\% (strongly agree and agree in total), organizational matters concerning the faculty $-77 \%$ and faculty members' scientific development - 74\% (table 2).

The respondents see relatively best conditions for participation in the development of didactics - 54\% (strongly agree and agree in total) (table 3 ). In the remaining cases related to submitting ideas for improvements critical opinions predominate, particularly in terms of the possibility to participate in the change in the organizational structure of the faculty $-56 \%$ (the total of strongly disagree and disagree) (table 3 ).

Despite their willingness and certain abilities created by the faculty, a significant percentage of respondents (39\% to 57\%) state they do not actually participate in the process of changing the faculty organizational structure. This includes gathering information related to change (57\%), search for possible solutions (55\%), and their evaluation (51\%) (table 4). The signs of participation are mostly cooperation (passive participation) and depend primarily on being informed, less frequently on the possibility to speak out. They mainly concern the implementation of the chosen solution (48\%) and recognition of the need for change (46\%). The examples of active participation (responses: right to object, common dispute settlement, and independent decision-making) are much rarer (table 4) and involve mainly the managing staff and senior academic staff members.

As table 5 shows employees are informed about the change usually by the immediate supervisor - $66 \%$, directly by the deanery, or other employees $-62 \%$ each. The significance of informal communication (gossip) is relatively large $-54 \%$.

The most frequently indicated techniques for employee participation in the change are information meetings with faculty authorities - $64 \%$ or departmental meetings - 57\% (table 6). In terms of the choice of individual, group or both forms of participation in the change, as many as $67 \%$ of respond- 
ents declare lack of participation in any of them (table 7). This is surprising due to the fact that the most commonly indicated participation techniques - information meetings - are a group participation technique (table 6).

In the opinion of $53 \%$ of respondents the faculty authorities apply the autocratic style (total of lines 1 and 2), making the decisions about the change without employee contribution. Another $31 \%$ of respondents indicate the consultative style (line 3), and only $8 \%$ indicate the participatory style (line 4) (table 8).

In addition, the respondents believe that the faculty authorities do not take into account the advice and opinions of employees in the process of changing the organizational structure - 47\% (disagree and strongly disagree in total), they do not work in agreement with employees - 46\%, they do not support employees in the implementation of targets connected to the change - $44.5 \%$, and they are not able to win the employees to cooperate in the change - $42 \%$. A relatively high percentage of respondents have no opinion on whether the change designers are honest and trustworthy - 46\%. In turn, the respondents favourably refer to the fact that the Dean's office informs the staff about results - 55\%, and sets clear goals connected to the change - 46\% (table 9).

Employees of the analysed faculty react with indifference (31\%) and resistance (30\%) to rebuilding its organizational structure. Twenty three (23\%) of the respondents actively engage in the change, including almost all managers (7 out of $9-11 \%$ of all respondents) and senior academic staff members (professors and associate professors, $11 \%$ of the total number of respondents). They are the ones who actively participate in the change (most often indicating the response I participate in common dispute settlement) (table 10).

Employees' reactions to the faculty organizational change are mainly influenced by the atmosphere at the university related to staff rotation - $81 \%$ (very big and big). Next factors are the strategy of faculty, and the attitude (actions) of immediate supervisors - 64\% each. The least significant determinants are the demographic situation of the country (34\%) and how the faculty is perceived by other units of the university (38\%) (table 11).

\section{Conclusion}

The study revealed that the staff of analysed faculty have greater motivation than possibilities to participate in the change of organizational structure and to submit suggestions for improvement. Their participation in the change often has a passive form and consists in being informed. Active participation is rare and generally limited to senior academic staff members (professors and associate professors) and managerial positions.

A significant percentage of respondents declare lack of participation in the change. The limited scope and dissemination of employee participation is evidenced by the fact that they are unable to properly identify the group form 
of their participation in the whole process, although group participatory techniques (information meetings) are commonly used.

The respondents claim that the designers of change most often use the autocratic style adverse to participation; the consultative or participatory styles are applied sporadically. Their attitudes and actions towards subordinates are variously assessed, and also assessed negatively.

Employees are usually indifferent to the change or resist it, although only one in five is engaged.

The most significant internal determinant of the respondents' reactions to the change is the atmosphere at the university linked to staff rotation and the attitude of the immediate supervisor. The most significant external factors are the overall atmosphere in the country around science and higher education, and work on the new law 2.0.

In conclusion it shall be indicated that in the analysed faculty of one of the higher education institution in the Pomeranian Province undergoing organizational changes the direct participation of research and academic staff and teaching staff occurs to a small extent at the faculty undergoing the organizational change. Little direct employee participation does not enhance proper employees' attitudes towards the change (cooperation and engagement) and does not counteract negative feedback in the form of resistance. Perhaps the employees were included too late, hence there was no time to invite them to a full participation in all stages of the process, which could have (in the light of the source literature) translated into a greater and more effective collaboration in the change cycle.

The direct participation of academic teachers could be introduced in higher education institutions through a system of ideas and suggestions offered by research and academic staff and teaching staff individually and collectively (e.g. through consultations or autonomous teams) regarding fulfilling the university mission (education of students - new subjects, specialties reflecting the needs of science). Therefore, academic teachers could initiate the organizational changes and actively participate in them (not to resist the change), which would help build universities' competitive edge in their professional surroundings.

\section{References}

Cabała, P. (2015). Determinanty sprawności systemu zarządzania zmianą organizacyjną. Zeszyty Naukowe Wydziału Zamiejscowego w Chorzowie Wyższej Szkoty Bankowej w Poznaniu, 17.

Clarke, L. (1997). Zarządzanie zmiana. Warszawa: Gebethner i Sk-a.

Czermiński, A., Czerska, M., Nogalski, B., Rutka, R., \& Apanowicz, J. (2001). Zarzadzanie organizacjami. Toruń: Dom Organizatora.

Czerska, M. (1996). Organizacja przedsiębiorstw. Metodologia zmian organizacyjnych. Gdańsk: Wydawnictwo Uniwersytetu Gdańskiego. 
Grobelna A., Sidorkiewicz, M., \& Tokarz-Kocik, A. (2016). Job satisfaction among hotel employees: analysing selected antecedents and job outcomes: case study from Poland. Argumenta Oeconomica, 2(37).

Grobelna, A., \& Marciszewska, B. (2016a). Undergraduate students' attitudes towards their future jobs in the tourism sector: challenges facing educators and business. In N. Khazieva, \& D.Vasilenko (Eds.), Proceedings of the 4th International Conference on Management, Leadership and Governance. London: Academic Conferences and Publishing International Limited Reading.

Grobelna, A., \& Marciszewska, B. (2016b). Work motivation of tourism and hospitality students: implications for human resource management. In C. Bagnoli, C. Mio, A. Garlatti, \& M. Massaro (Eds.), Proceedings of the 8th European Conference on Intellectual Capital. London: Academic Conferences and Publishing International Limited Reading.

Hodgkinson, A. (1999). Employee involvement and participation in the organisational change decision: Illawarra and Australian patterns. University of Wollongong Working Paper, 99-7.

Igielski, M. (2015). Management system of knowledge workers in the contemporary enterprise. In A.P. Balcerzak (Ed.), Contemporary Issues in Economy. Proceedings of the International Conference on Applied Economics: Management Sciences. Torun: Institute of Economic Research and Polish Economic Society.

Ignyś, A. (2014). Zaangażowanie pracowników w doskonalenie przedsiębiorstw: bezpośrednia partycypacja pracownicza. Prace Naukowe Uniwersytetu Ekonomicznego we Wroctawiu, 357. doi:10.15611/pn.2014.357.03.

Kaczmarczyk, S. (1999). Badania marketingowe. Metody i techniki. Warszawa: PWE.

Kizielewicz, J. (2015). Ethical standards for regional authorities in creation of strategy for regional development. In J.C. Rouso (Ed.), Proceedings of the llth European Conference on Management Leadership and Governance. London: Academic Conferences and Publishing International Limited Reading.

Koźmiński, A., \& Piotrowski, W. (2013). Zarządzanie. Teoria i praktyka. Warszawa: PWN.

Moczulska, M. (2011). Bezpośrednia partycypacja pracowników w zarządzaniu przedsiębiorstwem. Możliwości, przestanki, uwarunkowania. Zielona Góra: Oficyna Wydawnicza Uniwersytetu Zielonogórskiego.

Mowbray, P.K., Wilkinson, A., \& Tse, H.H.M. (2015). An integrative review of employee voice: identifying a common conceptualization and research agendas. International Journal of Management Reviews, 17(3). doi:10.1111/ ijmr.12045.

Pawlak, J. (2015). Podmiotowość i partycypacja pracowników a zaangażowanie i odpowiedzialność w zespole w sytuacji zmiany. Zeszyty Naukowe Uniwersytetu Ekonomicznego w Krakowie, 8(944). doi:10.15678/znuek.2015.0944.0805.

Radomska, J. (2010). Partycypacja pracowników w zarządzaniu w firmach europejskich, amerykańskich i japońskich. Wspótczesna Ekonomia, 4(2). 
Rees, C., Alfes, K., \& Gatenby, M. (2013). Employee voice and engagement: connections and consequences. International Journal of Human Resource Management, 24(14). doi:10.1080/09585192.2013.763843.

Robbins, S. (1998). Zachowania w organizacji. Warszawa: PWE.

Sobka, M. (2014). Zmiany organizacyjne $w$ teorii i praktyce. Lublin: Politechnika Lubelska.

Spodarczyk, E. (2016). The concept of corporate social responsibility in the micro and small enterprise sector. In F. Pinzaru, C. Bratianu (Ed.), Proceedings of the 12th European Conference on Management, Leadership and Governance. London: Academic Conferences and Publishing International Limited Reading.

Strykowska, M. (2010). Psychologiczne aspekty wdrażania zmian organizacyjnych. Organizacja i Kierowanie, 2.

Summers, J., \& Hymen, J., (2005). Employee participation and company performance. A review of the literature. York: Joseph Rowntree Foundation.

Szelągowska-Rudzka, K. (2015). Management style as determinant of employees direct participation in ICT industry: case study. In J.C. Rouso (Ed.), Proceedings of the 1lth European Conference on Management Leadership and Governance. London: Academic Conferences and Publishing International Limited Reading.

Szelągowska-Rudzka, K. (2016a). Czynniki wpływające na partycypację bezpośrednia pracowników: przegląd literatury. Przegląd Organizacji, 12.

Westhuizen, D.W., Pacheco, G., \& Webber, D.J. (2012). Culture, participative decision making and job satisfaction. International Journal of Human Resource Management, 23(13). doi:10.1080/09585192.2011.625967.

Wittig, C. (2012). Employees' reactions to organizational change. Od Practitioner, 44(2).

Zarębska, A. (2002). Zmiany organizacyjne w przedsiębiorstwie. Teoria i praktyka. Warszawa: Difin.

\section{Acknowledgements}

Author contributions: author has given an approval to the final version of the article.

Funding: this research was fully funded by the Gdynia Maritime University, Faculty of Entrepreneurship and Quality Science statutory sources. Publication was financed with a grant from the Ministry for Higher Education for statutory activities.

Note: the results of this study were presented at 9th International Conference on Applied Economics Contemporary Issues in Economy (June 22-23, Toruń, Poland). 


\section{Appendix}

Table 1.

The degree to which the employees of the faculty care about its smooth functioning

\begin{tabular}{ccccc}
\hline definitely agree & agree & neither agree nor disagree & disagree & definitely disagree \\
\hline 60.0 & 37.0 & 1.5 & 0.0 & 1.5 \\
\hline
\end{tabular}

Source: Own preparation.

Table 2.

The willingness to participate in the change of the faculty organizational structure and its improvement (in \%)

\begin{tabular}{|c|c|c|c|c|c|}
\hline \multirow{2}{*}{ Willingness } & \multicolumn{5}{|c|}{ Responses } \\
\hline & strongly agree & agree & neither agree nor disagree & disagree & strongly disagree \\
\hline $\begin{array}{l}\text { to participate in the change } \\
\text { of the faculty organizational } \\
\text { structure }\end{array}$ & 20 & 39 & 15 & 20 & 6 \\
\hline $\begin{array}{l}\text { to submit ideas and sugges- } \\
\text { tions for improvements relat- } \\
\text { ed to the change of the faculty } \\
\text { organizational structure }\end{array}$ & 25 & 36 & 15 & 18 & 6 \\
\hline to submit ideas and suggestion & for improvemen & s conce & ning: & & \\
\hline $\begin{array}{l}\text { - the faculty organizational } \\
\text { matters }\end{array}$ & 20 & 57 & 7 & 11 & 5 \\
\hline - the faculty didactics & 33 & 51 & 6 & 5 & 5 \\
\hline $\begin{array}{l}\text { - scientific development } \\
\text { of the faculty members }\end{array}$ & 30 & 44 & 8 & 15 & 3 \\
\hline
\end{tabular}

Source: Own preparation.

\section{Table 3.}

The employees' ability to participate in the organizational change and to engage in the faculty affairs (in \%)

\begin{tabular}{|c|c|c|c|c|c|}
\hline \multirow{2}{*}{ Ability } & \multicolumn{5}{|c|}{ Responses } \\
\hline & strongly agree & agree & neither agree nor disagree & disagree & strongly disagree \\
\hline $\begin{array}{l}\text { to participate in the change } \\
\text { of the faculty organizational } \\
\text { structure }\end{array}$ & 11 & 13 & 20 & 33 & 23 \\
\hline $\begin{array}{l}\text { to submit ideas and sugges- } \\
\text { tions for improvements relat- } \\
\text { ed to the change of the faculty } \\
\text { organizational structure }\end{array}$ & 12 & 16 & 26 & 30 & 17 \\
\hline \multicolumn{6}{|c|}{ to submit ideas and suggestions for improvements concerning: } \\
\hline $\begin{array}{l}\text { - the faculty organizational } \\
\text { matters }\end{array}$ & 13 & 23 & 18 & 30 & 16 \\
\hline - the faculty didactics & 16 & 38 & 15 & 21 & 10 \\
\hline $\begin{array}{l}\text { - scientific development } \\
\text { of the faculty members }\end{array}$ & 15 & 21 & 21 & 30 & 13 \\
\hline
\end{tabular}

Source: Own preparation. 
Table 4.

The actual way of participating in the change of the faculty organizational structure begun in the winter term of the 2016/2017 academic year declared by respondents (in \%)

\begin{tabular}{|c|c|c|c|c|c|c|c|}
\hline \multirow[b]{2}{*}{ Process stage } & \multicolumn{7}{|c|}{ Mode of participation in decision-making } \\
\hline & informing & $\begin{array}{l}\text { being able } \\
\text { to speak } \\
\text { out }\end{array}$ & advising & $\begin{array}{l}\text { right } \\
\text { to object }\end{array}$ & $\begin{array}{l}\text { common } \\
\text { dispute } \\
\text { settlement }\end{array}$ & $\begin{array}{l}\text { independent } \\
\text { decision- } \\
\text { making }\end{array}$ & $\begin{array}{c}\text { lack } \\
\text { of participation }\end{array}$ \\
\hline $\begin{array}{l}\text { recognition } \\
\text { of the problem - } \\
\text { the need for change }\end{array}$ & 30 & 13 & 3 & 2 & 8 & 2 & 42 \\
\hline $\begin{array}{l}\text { collecting informa- } \\
\text { tion on the prob- } \\
\text { lematic situation } \\
\text { (the need for change) }\end{array}$ & 23 & 5 & 5 & 0 & 8 & 2 & 57 \\
\hline $\begin{array}{l}\text { searching for } \\
\text { solutions }\end{array}$ & 23 & 11 & 3 & 0 & 12 & 0 & 51 \\
\hline solution evaluation & 20 & 11 & 3 & 2 & 10 & 0 & 54 \\
\hline $\begin{array}{l}\text { choice of ultimate } \\
\text { solution }\end{array}$ & 30 & 7 & 0 & 1 & 13 & 0 & 49 \\
\hline $\begin{array}{l}\text { preparation for } \\
\text { implementation } \\
\text { of chosen solution } \\
\text { (change) }\end{array}$ & 26 & 11 & 2 & 0 & 11 & 2 & 48 \\
\hline $\begin{array}{l}\text { implementation } \\
\text { of chosen solution }\end{array}$ & 33 & 12 & 3 & 0 & 10 & 2 & 39 \\
\hline
\end{tabular}

Source: Own preparation.

Table 5.

Key sources of information on changing the faculty organizational structure (in \%)

\begin{tabular}{lc}
\hline \multicolumn{1}{c}{ Sources of information } & Responses* \\
\hline own observation & 43 \\
immediate supervisor & 66 \\
the deanery directly & 62 \\
official e-mails & 39 \\
other employees & 62 \\
gossip & 54 \\
no information & 0 \\
other (specify...) & 0 \\
\hline
\end{tabular}

Note:

* — the respondents could choose more than one response, so they do not add up to $100 \%$.

Source: Own preparation. 
Table 6.

The most common techniques for employee participation used in the change of the faculty organizational structure (in \%)

\begin{tabular}{lc}
\hline \multicolumn{1}{c}{ Techniques of participation } & Responses* $^{*}$ \\
\hline information meetings with the faculty authorities & 64 \\
departmental information meetings & 57 \\
group solution search & 13 \\
submitting own ideas & 10 \\
other & 2 \\
no opinion & 2 \\
none & 18 \\
\hline
\end{tabular}

Note:

* — the respondents could choose more than one response, so they do not add up to $100 \%$.

Source: Own preparation.

Table 7.

The form of employee participation in the change of the faculty organizational structure (in \%)

\begin{tabular}{lcc}
\hline & Form of participation & Responses \\
\hline individual & 7 \\
group & 10 \\
both & 16 \\
none & 67 \\
\hline
\end{tabular}

Source: Own preparation.

Table 8 .

How change designers make decisions about changing the faculty organizational structure (management style) (in \%)

\begin{tabular}{lc}
\hline \multicolumn{1}{c}{ Way of decision-making } & Responses \\
\hline individually & 46 \\
by consulting individual employees & 7 \\
by consulting the situation (solution) with a group of employees & 31 \\
together with employees & 8 \\
I do not know & 8 \\
\hline
\end{tabular}

Source: Own preparation. 
Table 9.

Attitudes and behaviours of the change designers of the faculty organizational structure (in \%)

\begin{tabular}{|c|c|c|c|c|c|}
\hline \multirow{2}{*}{ Statement } & \multicolumn{5}{|c|}{ Responses } \\
\hline & strongly agree & agree & I don't know & disagree & strongly disagree \\
\hline they set clear goal connected to the change & 8.0 & 38.0 & 16.0 & 25.0 & 13.0 \\
\hline $\begin{array}{l}\text { they support employees in the implemen- } \\
\text { tation of goals }\end{array}$ & 3.0 & 21.5 & 31.0 & 23.0 & 21.5 \\
\hline they work in agreement with employees & 3.0 & 21.0 & 28.0 & 23.0 & 23.0 \\
\hline they inform employees about results & 2.0 & 53.0 & 18.0 & 16.0 & 11.0 \\
\hline they consider employees' advice, opinions & 5.0 & 11.0 & 38.0 & 25.0 & 21.0 \\
\hline $\begin{array}{l}\text { in a difficult situation employee can count } \\
\text { on their support }\end{array}$ & 8.0 & 17.0 & 39.0 & 16.0 & 20.0 \\
\hline $\begin{array}{l}\text { they treat employees on a subjective basis } \\
\text { (employees are important) }\end{array}$ & 11.0 & 25.0 & 33.0 & 16.0 & 15.0 \\
\hline $\begin{array}{l}\text { they care about employees and their future } \\
\text { at the university }\end{array}$ & 7.0 & 21.0 & 36.0 & 16.0 & 20.0 \\
\hline they are honest and trustworthy & 6.5 & 28.0 & 46.0 & 6.5 & 13.0 \\
\hline $\begin{array}{l}\text { they can win employees to cooperate } \\
\text { in the process of OC }\end{array}$ & 8.0 & 11.0 & 39.0 & 25.0 & 17.0 \\
\hline
\end{tabular}

Source: Own preparation. 
Table 10.

Respondents' reactions to the change in the faculty organizational structure (in \%)

\begin{tabular}{lc}
\hline \multicolumn{1}{c}{ Respondents' reaction to the change } & Responses \\
\hline the change is neutral to me because: & 31 \\
- I am not fully informed about it & 2 \\
- I do not know why it is being implemented & 2 \\
- I am afraid that it is going to be adverse for me & 0 \\
- I have no confidence in the managing staff and their change design & 0 \\
- I was not invited to participate in the change & 3 \\
- I have bad previous experience with the way of implementing changes at the faculty & 3 \\
I only engage when it is beneficial for me & 15 \\
I only engage when it is possible & 1 \\
I engage in the change, actively cooperating in implementation & 23 \\
I resist the change because: & 30 \\
- I am not fully informed about it & 18 \\
- I do not know why it is being implemented & 13 \\
- I am afraid that it is going to be adverse for me & 10 \\
- I have no confidence in the managing staff and their change design & 8 \\
- I was not invited to participate in the change & 10 \\
- I have bad previous experience with the way of implementing changes at the faculty & 5 \\
\hline
\end{tabular}

Note:

* - people who responded 'the change is neutral...' and 'I resist' could indicate more than one specific cause for this reaction; the percentage of the specific indications is related to the number of all respondents.

Source: Own preparation. 


\section{Table 11.}

The impact of the following factors on the behaviour of respondents in relation to the change in the faculty organizational structure (in \%)

\begin{tabular}{|c|c|c|c|c|c|c|}
\hline \multirow{2}{*}{ Factors } & \multicolumn{6}{|c|}{ Responses } \\
\hline & very big & big & neither big nor small & small & very small & none \\
\hline $\begin{array}{l}\text { the atmosphere at the university caused by } \\
\text { staff rotation }\end{array}$ & 48 & 33 & 11 & 1 & 0 & 7 \\
\hline strategy of the University & 30 & 24 & 30 & 5 & 5 & 6 \\
\hline strategy of the Faculty & 25 & 39 & 23 & 2 & 3 & 8 \\
\hline system of motivating faculty employees & 17 & 25 & 28 & 11 & 8 & 11 \\
\hline financial situation of faculty & 26 & 23 & 28 & 10 & 3 & 8 \\
\hline $\begin{array}{l}\text { the way the faculty is perceived by other core } \\
\text { units of the university }\end{array}$ & 12 & 26 & 31 & 8 & 8 & 15 \\
\hline the attitude/actions of immediate supervisors & 23 & 41 & 21 & 5 & 3 & 7 \\
\hline $\begin{array}{l}\text { work on the new law on higher education } \\
\text { and resulting possible directions of changing } \\
\text { the system }\end{array}$ & 15 & 34 & 28 & 5 & 5 & 13 \\
\hline the country's demographic situation & 3 & 31 & 31 & 7 & 15 & 13 \\
\hline $\begin{array}{l}\text { general atmosphere in the country concern- } \\
\text { ing science and higher education institutions }\end{array}$ & 17 & 33 & 21 & 13 & 3 & 13 \\
\hline
\end{tabular}

Source: Own preparation. 
